\title{
11
}

\section{One Hundred Years of Social Protection: The Rise of the Social Question in Brazil, India, China, and South Africa, 1920-2020}

\section{Lutz Leisering}

This volume ventures into a largely uncharted territory, enquiring if, when, and how the social question has been raised in four countries over the last hundred years - countries that are better known as "emerging markets" in the early twenty-first century. Assuming that the social question reflects problems of social integration in modernising societies against the background of modern ideas of equality and human rights, the contributors to this volume investigate social policies in the four countries, starting from the interwar years, with special emphasis on social protection.

The volume provides an analysis focused on ideas reflected in contemporary documents-ideas as a strand of social protection in their own right and as legitimising and constituting interests and institutions. Ideas are a key factor in explaining the rise of social protection, as depicted in

\footnotetext{
L. Leisering $(\bowtie)$

Department of Sociology, Bielefeld University, Bielefeld, Germany e-mail: lutz.leisering@uni-bielefeld.de 
Gough's summary explanatory model of the "Five Is" (see Chap. 1, Fig. 1.1). The volume takes a historical approach to overcome the presentist bias of the current literature on social policy in the Global South. Midgley's (1984) historical study, now a classic, went largely unnoticed at the time of publication.

In addition to our substantive research interest, we also seek to contribute to theorising Southern welfare. Accordingly, in this concluding chapter, $\mathrm{I}^{1}$ present the main findings of the country-focused chapters in a comparative perspective and framed by five overarching concepts- historical evolution, social construction, political language, multireferentiality, and transnational diffusion - that build on the theoretical framework developed in Chap. 1. The five concepts can generally serve as a conceptual template for studies of social protection in Southern countries. For each of the five concepts, I give examples, counterexamples, and specifications from the country studies. The chapter closes with theoretically and empirically grounded thoughts about the future of social protection in middle-income countries.

The first finding relates to the historical evolution of social protection: the hundred years from 1920 to 2020 mark the rise of social protection programmes in the four countries. The second finding relates to the social construction of the social, that is, to the articulation of "social" issues: all four countries, except India, have articulated social issues in a generalised way as a social question, which is the core of a multi-layered configuration of social ideas, as conceptualised in the onion skin model (see Fig. 1.2, Chap. 1). The third finding concerns political language: the use of "social" semantics has spread in all four countries. The fourth finding concerns "multireferentiality", that is, the linkage of social protection to diverse ideas and interests beyond purely "social" ideas (like social justice or solidarity): social protection policies were largely driven and shaped by "non-social" ideas and interests that acted as frames. The fifth finding

\footnotetext{
${ }^{1}$ As in Chap. 1, "I" refers to the author's views and arguments, while "we" refers to the volume's contributors' views and findings. I thank Sony Pellissery, Marianne Ulriksen, Gabriel Ondetti, Hu Aiqun, and Jeremy Seekings for comments which helped to improve the chapter (the latter gave particularly extensive comments). I am also indebted to John Berten for communication on the history of the terms "social insurance" and "social security", and to Ravi Ahuja for explaining to me the meaning of socialism in India.
} 
describes the transnational diffusion of ideas: external ideas have pervaded domestic social protection policies from the beginning, testifying to the rise of world society, conceived as a global consciousness and shared world culture (Meyer 2007: 262f.).

\section{Historical Evolution: 1920 to 2020 Was the Century of Social Protections for These Four Countries}

In Europe, the social question arose in the 1830s and 1840s, and substantial social policy measures were taken from the 1880s onward. After World War II, the "welfare state" as a new type of state and society unfolded. Social policy in the Global South, including our four countries, came later but not as late as often assumed. When we initiated our collaborative research project, we first thought of starting with the 1940s. However, the empirical evidence taught us to start earlier. We found that all four countries had an early start regarding ideas and actual legislation. This is our first finding on the evolution of social protection policies. Between 1920 and 1950, many of the basic social categories that were used in later debates already figured in politics. The year 1920 is not a neat cut-off point, though. Some social ideas and (highly selective) measures started earlier, such as the ideas of Duguit and Torres on land reform $(1911,1914)$ that were applied in Brazil later, the famine codes in late nineteenth-century India, and the late nineteenth-century and early twentieth-century debates on the "cost of living" in Brazil.

We know that social protection policies do not simply reflect socioeconomic conditions, as the functionalist theory of the "logic of industrialisation" assumed in the 1960s. Instead, political factors mediate processes of industrialisation, urbanisation, and dislocation. Although the four countries started social protection roughly around the same years, they did so at different levels of economic development, except China and India which started from the same very low level (see Chap. 1, Table 1.3). 
The second finding regarding the evolution of social protection is, as expected, the expansion of social protection over the last hundred years. The social question was articulated in an increasingly inclusive way, and new discourses, actors, and categories relating to the social emerged. Moreover, older debates, doctrines, and actors were "socialised", that is, they turned to social issues. Even in periods of upheaval, war, and civil war, and under democracy and dictatorship alike (the latter in Brazil from 1930 to 1945 and 1964 to 1985 and in China since 1949), social protections were debated and legislated. There were periods of intensified social policy activity, as in South Africa from 1924 to 1933, Brazil from 1930 to1945, India from 1946 to 1952 , China from the 2000s until the early 2010s, and during the 1940s in all four countries. In South Africa, a key component of the national social protection arrangement, old-age pensions, did not change much during apartheid.

The finding of overall expansion needs qualification. First, there were periods of retrenchment, notably in China during the early reform era (1978-2000), similar to what Rimlinger (1971) calls a "liberal break" in his analysis of the rise of Northern social policy. This describes a period in which older welfare institutions (in the case of China: socialist welfare) are crumbling, while new institutions that would address the social problems ensuing from economic liberalisation are still rudimentary. Second, expansion mainly refers to the extension of coverage and not necessarily to raising benefit levels and improving the quality of services. Third, there was massive decoupling or delayed coupling between ideas and legislation and also between legislation and implementation, as in the case of the Employees' Social Insurance Act of 1948 in India. Implementation was often deficient or absent. Debates tended to produce an ideational surplus, which could reflect either empty promises or powerful ideas that would mobilise people and fuel later reforms. In Brazil, decades of calls for thoroughgoing land reform produced very modest results, even under leftist governments. In Brazil, there was also a gulf between the Constitution, which is rich in social promises, and the reality of social services and living conditions. India's history is replete with ideas that created a "horizon of expectation" (Ahuja), which largely remained a 
horizon. In China, the implementation of the industrial accident insurance has been very patchy (Liu and Leisering 2017).

Did the early beginnings of social protection ideas and programmes constitute an institutional path? The answer is mixed. There is evidence of social protections' institutional continuity across major historical junctures (qualifying Piachaud and Midgley 2013: 267). This seems to indicate that the institutional arrangements of social protection may have acquired a dynamic of their own early on. Post-apartheid South Africa largely built on the institutional legacy of the apartheid era. Even the deracialisation of social protection began in the early 1940s, accelerated in the 1980s, and was completed in the 1990s. New programmes like the Child Support Grant built on programmes set up under the apartheid regime and before. In Brazil, social protection remained labourist under both democratic and authoritarian governments, and even Vargas' farreaching social reforms built on earlier institutionalisations of social protections.

However, the year of the foundation of the People's Republic of China, 1949, marked a break with earlier periods: socialist social protection and the Soviet variety of social insurance associated with Stalin replaced earlier institutions in the 1950s (but Taiwan built on the pre-1949 legacy). There were further significant departures from or extensions of historical paths. While Brazil remained labourist overall, Brazil's early introduction of a non-contributory rural pension in 1971 was remarkable, as was Brazil's pioneering role in the field of social cash transfers in the late 1990s and early 2000s. Regarding the latter, it is an open question whether the mushrooming of social cash transfers for the poor across the Global South indicates a new social model even in countries that had been labourist for a long time. China is the country with the most conspicuous path changes, from socialist social protections (1949/1951-1978), to a liberal period of retrenchment (1978-2000), then more inclusive social protections (2000-2012), and finally, more authoritarian "social governance" thereafter. 


\section{Constructing the Social: All Four Countries, India the Least, Have Articulated Social Issues as a Social Question}

In all four countries, India the least, a social question was voiced, and generalised terms like social insurance and social security emerged. Social problems are ubiquitous in any society but they are not necessarily articulated, that is, turned into a public issue. In most societies, some social problems are articulated, but few societies voice a generalised concern for social issues as a threat to the integration of society to be tackled by the state, that is a social question.

The social question has three facets: first, the social question reflects "objective" socio-economic conditions, such as industrialisation, dislocation, urbanisation, wage labour, factory labour, and de-agrianisation. Second, it refers to intellectuals, experts, politicians, and social movements' articulation of such conditions as a general concern for society to be addressed by the state. These articulations may be ahead of the socioeconomic conditions of the country, like raising the labour question in a largely agrarian society (as some early critics of social protection in India argued), or they may lag behind, underrating the scale of social problems. Third, the social question involves references to political measures to be taken in response to the articulated social problems. Each of these three facets or dimensions has its own history. They are related but in a contingent way - a loose coupling.

The country-centric chapters identify three main varieties of the social question-in historical order: the land question, the labour question, and a less distinct variety that I propose to call "exclusion/inclusion". Furthermore, there are variants of the three main types, and other, more specific social questions, such as the poverty question (which heralded "exclusion/inclusion") and the hunger question, which has been particularly central to Indian politics and is related to the issue of food security. The three main varieties of the social question do not represent distinct historical stages. The land question often co-existed with the labour question, and the seeds of "exclusion/inclusion" were sown early on, through the poverty question, as in South Africa from the 1920s. 
The land question - or agrarian question - was first. This cannot come as a surprise, considering that agricultural production and related ways of living prevailed during the early years of industrialisation. Pellissery and Lødemel (2020) make a case that property rights in land remain an essential component of social citizenship today. In Brazil, both anti-feudalism and anti-capitalism played a role in the struggle over land reform, as did the ideas of early reformist thinkers, especially Duguit and Torres, and, towards the end of our observation period, novel ideas like agroecology and food safety that redefined the land question. In China in the 1920s, Sun Yat-Sen posited the land question as the social question, and in the aftermath of the revolution in 1949, the People's Republic of China achieved the only thorough land reform among the four countries.

The labour question or workers' question came second, confining the social question to workers and, more specifically, to formal workers and, originally, to selected groups of industrial workers only. As Ahuja argues for India, the distinction between formal and informal workers, which is crucial for social protection across the Global South, was created in the process. In India, even the very category of "labour" emerged as a legitimate political category in the decades before independence (Ahuja 2018: 319). The labour question revolved around work issues, especially working conditions, individual labour rights, and collective labour rights, that is, the right to collective action through unions to empower the workers vis-à-vis employers and markets. Social protection was part of the labour question in the shape of social insurance programmes. Most countries in the Global South introduced industrial accident insurance-sometimes called workmen's compensation - as the first branch of social insurance (Usui 1994), and this branch is most closely related to labour issues. Brazil was strongly labourist, with Vargas establishing state corporatism. China was labourist to a degree before 1949 but more narrowly so in succeeding decades. South Africa was mixed pauperist-labourist, focusing on the "poor white problem" in the 1920s and 1930s and the racialised "civilised workers' question" under apartheid; but public and semi-public social insurance was weakly developed. India was labourist with regard to a very small group of workers, and social protections even for these workers were limited; yet, the construction of the social question as the labour question culminated in the labour legislation of the 1940s. 
The more universalistic question of exclusion/inclusion came later and extended beyond formal workers to the poor and possibly all citizens, including informal workers, the rural population, women, and persons with disabilities. In South Africa, the poverty of white persons was articulated as a social problem in the early and mid-twentieth century because it questioned the racial hierarchy. The "poor white problem" was primarily a problem of non-workers, especially persons who could not work due to age, infirmity, disability, or children (single mothers) and could not support themselves out of employment-related insurance. They should get work and the children should receive schooling. More inclusive policies started during the last decade of apartheid to be further developed in the 1990s, and during the 2000s, the discourse became more inclusive. In Brazil, the Constitution of 1988 was a major boost to social policy, and since 1988, belief in "social inclusion" became dominant across political ideologies (Pereira and Bertholini 2017). In China, the 2000s and early 2010s witnessed more inclusive policies associated with broader ideas, such as "inclusive growth", "humanity-based" policies, and "rights". In South Africa, "dignity" and "social rights" came to the fore in the same years, underpinning a universalistic agenda responsive to the needs of the poor; in a less pronounced way, this also happened in India. In India and South Africa, references to social rights introduced the courts as actors in social protection. Social protections geared to the poor, mainly cash transfers, were generally established late, spreading from the 2000s onward, with precursors in South Africa (1928) and in Brazil (1971). India had been concerned with the hunger question since the latenineteenth century but gave prominence to the needs of the poor and hungry at a fairly late stage and in particularistic ways: the fifth Five-Year Plan (of 1974) first put poverty on the country's agenda. In South Africa, what could be called the "deviance question" also mattered. It referred to the problem of delinquency and morally improper behaviour by poor white persons, which the state tried to address through social work and institutional care.

The three social questions sometimes intertwined. For example, we can interpret the introduction of a non-contributory rural pension in 1971 in Brazil as a way of alleviating the land question. In South Africa, the poverty question also intersected with the land question. From the 1920s 
through to the present, the expansion of social assistance in South Africa was necessitated by-and understood in terms of - the decline of agrarian society, first among "poor whites" because of the commercialisation of "white" farming and then among the black majority as a result of dispossession of and forced removals off the land. ${ }^{2}$

Remarkably, the earliest and most privileged welfare provisions, namely for persons close to the government-public sector employees, soldiers, teachers, and the like-were not normally discussed in the context of a social question. Instead, it seems that the need for these provisions was taken for granted, as in Europe, where provisions for persons in the public sector were the earliest forms of state social protection, starting in the eighteenth century, apart from public poor relief introduced in the sixteenth century.

The social question was not ubiquitous. China and India are examples of this. When China was socialist in the strict sense (1949-1978), the social question was dormant, assumed to be resolved in the institutions of socialism. Social protection was embedded in the socialist institutions of production: the rural People's Communes, the state-owned enterprises, and the urban work units. In sociological terms, these were functionally diffuse institutions in which the welfare function was weakly differentiated. Every person was assumed to be integrated into the socialist organisation of work and, thereby, covered by social protection. The state-owned enterprises provided social insurance but of the statist Soviet-type associated with Stalin (Hu and Manning 2010). In the People's Communes, a plot of land, to which every person had access by birth, sustained the members' welfare. In the socialist institutional setting, a social policy community could not develop, and the supremacy of the Communist Party left little room for the open articulation of social problems. Civil society and non-governmental organisations were non-existent.

The absence of the social question under socialism makes sense, at least theoretically, since socialism is designed to extinguish capitalist markets and the attendant social damages. During the negotiations that led to the Universal Declaration of Human Rights, 1946-1948, the Soviet Union

\footnotetext{
${ }^{2}$ The early introduction of old-age pensions for farmers in European countries also reflected a link between social protection and the land question (Leisering et al. 2002: 58-61).
} 
maintained that its socialist institutions already realised social rights-a socialist understanding of social rights as human rights that differed from liberal understandings (Davy 2014). In the communist German Democratic Republic (1949-1990), the very notion of "social policy" was suspect till the mid-1960s (Schmidt 2013: 30).

After the dormancy of the social question in socialist China, the Chinese government explicitly denied the social question during the liberal break period (1978-2000) when they delegated the social responsibility of the state to non-state actors under the flag of "socialisation". When I acted as a consultant to the Chinese government in 2001 (Leisering et al. 2002), many Chinese actors still denied the need for state-provided old-age pensions in rural areas; they referred to the land and family as sufficient resources for living. South African state officials used a similar argument to justify the exclusion of poor African people from social pensions and other kinds of social assistance in the 1920s and 1930s, as well as during the first decades of the apartheid regime.

In India, the social question was stifled throughout the last hundred years because of the cultural denial of equality in the Hinduist tradition. Individualised measures of social protection were weak, often eclipsed by "socialist" macroeconomic policies. In the late 1940s and the 1950s, the Indian Congress proclaimed a socialist orientation, and "socialism" was even included in the constitution in 1976. However, "socialism" only indicated a kind of etatism that comprised policies like Soviet-style planning, state regulation of industries, and Keynesianism. In later decades, particularistic, identity-based claims to social protections relating to the dalits and adivasis curtailed the social question.

\section{State Responsibility, Policy Paradigms, and Welfare Models}

In theoretical terms, the social question is the pivotal middle layer in the onion skin model of social ideas. It is related to the top and bottom layers of the model — to the social responsibility of the state, policy paradigms, and models of social protection-but in a contingent way. 
State Responsibility. The articulation of the social question puts demands on the state as the addressee of social responsibility. Remarkably, all four countries hold strong notions of national statehood, even in the face of marked divisions based on ethnicity, religion, caste, and the rural/ urban divide. Before 1949, the Chinese state was weak: warlords ruled in the immediate aftermath of the fall of the Empire, and, afterwards, the conflict between the Nationalist Party and the Communist Party led to civil war and regional divisions. The joint war against Japan added to the upheaval. During the 1920s and 1930s, Chinese intellectuals studied Western ideas of an organic society. After 1949, the People's Republic proclaimed state socialism, underpinned by a symbiosis between state and party. However, up until 1978, the social organisation of the country was actually decentralised, comprised of a large number of collectives, mainly the rural People's Communes, the state-owned enterprises, and the units of the state and party. In the first two decades of the reform era, that is, after 1978, the state retreated from social welfare provisioning. From 2012, the party-state has deepened.

Since independence, India has been a democracy and as such potentially responsive to social issues. Although the proclamation of "socialism" conjured up the notion of a strong state, the federal structure allowed for highly divergent social policies in the various Indian states, and some Indian states, such as Kerala, became quasi-welfare states (Singh 2015a, b). In the 1940s debates on the future of Indian society, Gandhi advocated a model of local communities that would have precluded a strong "social" state. The South African state was deeply racialised. Through the creation of separate "homelands" for black persons in the 1960s and 1970 s, the state surrendered its social responsibility for many of its citizens in the most extreme form.

Policy Paradigms. What policymakers define as the problem to be tackled is a key element of a policy paradigm. Countries may define very different groups as problem groups that deserve state-provided social protection. In China, "social problems" were discussed in the 1920s in both Marxist and non-Marxist terms. Persons close to the government and, for example in South Africa, war veterans, were considered the most deserving. Socio-economically defined groups, above all workers, were the centre of the labour question, but countries differed as to which branches of 
industry were covered by their social insurance programmes (for Brazil, see the historical study by Lewis and Lloyd-Sherlock 2009). Life-course groups, above all children and older persons, were also key addressees, mostly by means-tested programmes, that is, based on need. South Africa (old-age pensions in 1928) and Brazil (rural pensions in 1971) were pioneers. In the move towards social cash transfer programmes since the early 2000s, life-course groups are the main targets (Leisering 2019: 161, 181), while non-disabled persons of working age-the working poor, unemployed, and underemployed-mostly lack own entitlements (also in our four countries), calls for universal rights-based benefits notwithstanding. In India, social protection focuses on identity groups based on caste. Few countries define the addressees of basic income security in a non-categorical way, purely by need; the Chinese cash transfer programme Dibao and some provisions under Brazil's Bolsa Família are examples. ${ }^{3}$

Models of welfare institutions. A range of models emerged over the hundred years: the most common was and still is the model of social insurance, which is closely associated with the labour question. However, non-contributory social assistance programmes also figured early on, for example, in 1928 in South Africa. Towards the end of our observation period, since the 1990s, more universalistic models have arisen or been called for. The new social cash transfer programmes, mostly a variety of social assistance (only 20 per cent of the programmes are not meanstested; Leisering 2019: 169f.), are designed to make up for the limitations of social insurance programmes. State-regulated private protection, such as industrial accident insurance in Brazil in the 1920s, may also reflect a social concern of the state.

\section{Tracing the Social Question}

In Chap. 1, I have defined the concept of "social question": "Raising the 'social question' means that a society recognises social issues in a generalized way as a key concern of society, to be addressed by the state, linked

\footnotetext{
${ }^{3}$ The Indian Mahatma Gandhi National Rural Employment Guarantee Act is a public works programme rather than a social cash transfer programme.
} 
to a call for political remedies. The underlying assumption is that the state is responsible for individual welfare". When applying the concept in empirical studies, we need to operationalise it. How can we ascertain if the social question is raised in a particular country or not? Since some social issues are articulated in some way in almost any society, we need to define more precisely what we mean by the "social question". This is not normally done in the literature, for example, not even by Heclo in his article "The social question" (1995), who, like Castel (2003: xix f.), defines the social question through its intended effect, namely societal integration. Such a functionalist definition is unsatisfactory because there are functional equivalents to the social question: rulers may seek to secure societal integration through nationalism, mobilisation for war, or religious fundamentalism.

Based on the test of the concept in the chapters on the four countries, I propose eight criteria for ascertaining if, and to what degree, a society raises a social question:

1. Social issues must be seen as a challenge for a society or nation state as a whole-for societal cohesion and integration, as emphasised by Heclo (1995: 675) and Castel (2003: xix f.), or for the modernisation and development of a society-rather than only for sectional groups or particular institutions. Raising the social question implies a vision of society. In India and China during the 1920s, the call for social protection was part of a call for modernisation and overcoming the "backwardness" of the countries. In South Africa, the social question referred to the need to protect the existing racial hierarchy and the "civilisation" of the white settlers. In the new, post-2012 era in China, social protection is part of the Party's vision of a "middle well-off society" and the "Chinese Dream".

2. The social question reflects a generalised, comprehensive understanding of and interest in social issues rather than a reference to a particular social problem or welfare programme.

3. The social question is not just a list of measures to be taken by government, but involves the explication of an underlying idea or even "cosmology”, as Kaufmann (2013a: 33) puts it (see the quote in Chap. 1). 
4. The articulation of the social question needs to go along with the explicit attribution to the state of a social responsibility for the welfare of the citizens and calls for political action. The more the social question goes along with equally comprehensive concepts in the other layers of the onion skin models - the more it is linked to a far-reaching attribution of social responsibility to the state and the more it gives rise to elaborate policy paradigms and complex models of welfare institutions - the more it is entrenched in politics and society.

5. The social question must appear on the agendas of parliament, political parties, social movements, or in development plans or other relevant documents.

6. The social question must have a significant weight in public debates as compared to other societal concerns. To trace the social question, we need to find out how social issues are related to concerns like the national question or economic development.

7. Social issues must be referred to in terms of individual welfare, instead of only in terms of collective welfare to be achieved through economic growth. Accordingly, the social question needs to refer to the state and state policies rather than the economy. However, the reference to the state may include state regulation of the economy.

8. The social question, to be more than an empty promise, needs a degree of institutionalisation. This includes the creation of government departments specialising in welfare issues, as happened in all four countries. The department of labour or separate departments of social welfare may cover social issues. The emergence of epistemic and expert communities as well as political parties with "social" agendas and discourses give substance and sustainability to the social question. The social question also has a cognitive side: surveys of living conditions, commissions on social problems, social reports, and the like provide informational bases for social policies. In post-apartheid South Africa, there was a "mania for measurement", and social researchers played a role in conceptualising social reforms. The British tradition of parliamentary commissions influenced South Africa and India.

These eight defining characteristics of the social question can also be used as a template for comparative research. The range, depth, and 
content of the social question also depend on the arenas of political deliberation and discursive spaces. Zacher (2013: 87-109) emphasises that the welfare state requires the institutions of liberty to enable free deliberations on the social question according to the changing needs of and ideals among citizens. Authoritarian regimes put severe constraints on public deliberations, including, among others, freedom of the media. Especially since 2012, China has constrained civil society activity, relying on GONGOs (government-organised non-governmental organisations) instead to secure Party policies. In democratic societies, illiteracy and high morbidity rates may act as constraints on public deliberations, as in India and South Africa, respectively (see Table 1.2 in Chap. 1).

\section{Political Language: The Spread of "Social" Semantics}

Ideas are closely connected to language. Changes in ideas may be associated with changing semantics, but new ideas can also emerge using existing language, through reinterpretation of terms-new wine in old bottles. And vice versa, old wine in new bottles, is also common. The rise of social ideas often corresponds with a new language for talking about social problems and welfare institutions (for Northern countries see Petersen and Béland 2014a).

In all four countries, social-oriented language has spread, including new terms that indicate a generalised understanding of social issues beyond miscellaneous social grievances that can be found in any society. The key comprehensive terms that figure in all four countries are "social insurance"-denoting a generalised model of welfare; "social security" a generalised policy paradigm; and, less pronounced and more contested, "welfare state" - a term that reflects a generalised understanding of the state's social responsibilities. This list also outlines the historical order in which they appeared and the increasing abstraction of the concepts. "Social security" occupies an intermediate position between the narrower concept of "social insurance" and the wider concept of the "welfare state". 
The term social insurance was the earliest term used that went beyond individual problems and programmes. The ILO, which champions the social insurance model (Seekings 2008), has used the term from the beginning of the period under review (e.g. ILO 1925; see Berten 2020). In the period's early years, the narrower term "labour insurance" was in use, as in China in the 1920s and 1930s and in China's 1931 Constitution. However, participants had already referenced "social insurance" in the Communist-led second Labour Conference in 1925, and the Nationalist government referred to it in 1941. Social insurance was (and still is) a comprehensive term, since it covered a comprehensive range of basic social "risks" that the ILO codified. In this way, "social insurance" bore the seeds for extending social protection beyond the group of formal workers because the list of covered risks extended beyond the risks of work to the general contingencies of everyday life, and the reference to the workers' families and dependents potentially opened up a broader range of addressees, including women.

Social security as a term came later, in the 1940s, and turned into a platform for extending the scope of social protection. In India, the Indian National Congress first mentioned the term in 1940, but mainly limited to labour welfare. In South Africa, a movement, committee, and plan all referred to the term in 1942. In China, the term became official from 1945 onwards and was even included in the Constitution in 1946/1947. China seems to be the only country in which the term disappeared for a significant period of time: the law of 1951 refers to "labour insurance" and the term "social security" did not appear in the Constitution of 1954, but reappeared in the 2004 Constitution (and already 1986 in the Seventh Five-Year Plan) and was put into practice in the policies of the 2000s. In Brazil, the term "social security" entered into law as late as 1988 in the new Constitution and encompassed social insurance, universal healthcare, and social assistance.

The welfare state is a broader concept than the other two (Petersen and Béland 2014b: 298) and, even more than the others, refers both to provisions and ideational underpinnings or even cultural beliefs. The term "welfare state" is less frequently used in the four countries and highly contested. In South Africa, President Zuma explicitly rejected the idea of a welfare state, as the National Party had emphatically done already under 
apartheid, for example, in Parliament, although, remarkably, the National Party had been happy with the notion of a "social welfare state".

However, regarding the scope of social protections, actual developments, or at least policy goals developed towards what could be called a "welfare state". Seekings (Chap. 6) describes South Africa as a "nascent welfare state" by 1949. The "four principal social policies" that China's Nationalist Party (Guomindang) articulated in 1945 also came close. The welfare state is a key element of the self-image of societies in Britain, Germany, and the Nordic countries, but it is an open question if this will ever occur in the four countries that we investigate or many other Southern countries. Regarding social effort, even Southern countries with fairly comprehensive social protections spend much less on public welfare (see Fig. 1.5 in Chap. 1) than do Northern welfare states (which spend 20-35 per cent of their GDP).

There are several other comprehensive terms. The oldest and most comprehensive is "social policy", which was mentioned in South Africa as early as 1934. The term originated in mid-nineteenth-century Europe and spread globally throughout the twentieth century (Kaufmann 2013b: 36-39 and passim). More recent expressions, mostly spreading since circa 2000 , include "social protection", which has a somewhat broader meaning than "social security", "social pensions", "corporate social responsibility", "social sustainability", "social safety nets" (World Bank 2018), and "social cash transfers" (for the origin of the latter term see von Gliszczynski 2015: 28-30). The proliferation of terms with the component social testifies to the increasing recognition of social issues across the globe.

What is the meaning of the inconspicuous word "social"? The precise meaning of "social" in the context of social policy is difficult to pin down: "the systemic character of social policy is not nearly as evident as that of the market economy. What 'the social' means in distinction to the economic and the political, or in other words: which social phenomena and problems are relevant as the effective sphere of social policy and why-to this day no clarity has emerged on this question" (Kaufmann 2013b: 97-98). In common usage, the "social" is often set in opposition to the economic or, alternatively, to the individual. Historically, "social" as an idea and a term originated in France and Germany in the 1830s and 1840s (Kaufmann 2012: chapter 2; Kaufmann 2013b, c) and was used in 
the then-new terms "social reform", "social policy", "social question", and others (Pankoke 1970). "Social" implies the recognition of the cleavage between the modern political ideal of equality and the socio-economic inequalities of emerging industrial-capitalist societies, which the German philosopher Hegel (1770-1831) first explicated in systematic terms. While Marx's solution to this cleavage was to overthrow capitalism, his contemporary Lorenz von Stein (1815-1890), like Marx (1818-1883) a Hegelian, conceived of social policy (sociale Politik) as a way to bridge and mitigate this cleavage by reforming capitalism. Accordingly, social policy and the social question are reformist rather than revolutionary policy concepts.

\section{The Career of "Social Security"}

As expected, "social security" has been a key term and idea in the history of social policy in the four countries. Therefore, it is worth tracing the career of the term beyond its appearance in the four countries.

According to the authoritative study on the concept of security (Kaufmann 1973, 2012: chapter 5), "security" is a key normative idea of modern society or, more specifically, of the functionally differentiated society, as systems theorists conceive of modern society. Marx identified security as the overarching idea of civil society (or of capitalism, as he later termed it): "Security is the supreme social concept of civil society ..." (Marx 1978: 43). ${ }^{4}$ Social security is a variety of the broader concept of security. While "social", the "social question", and other related terms emerged in the second third of the nineteenth century, the term "social security" only emerged a century later. One might have expected "social security" to originate in Western and Northern Europe, but the first use of the term is commonly attributed to American President Franklin Delano Roosevelt in 1934, and the term figured explicitly in the name of the US "Social Security Act" of 1935, which was part of the New Deal. Yet only the term was new; it hardly conveyed new ideas that were previously unknown in Europe (Kaufmann 2012: 135).

\footnotetext{
${ }^{4}$ German original: "Die Sicherheit ist der höchste soziale Begriff der bürgerlichen Gesellschaft ..." (Marx 1956: 365; written in 1843).
} 
In international arenas, "social security" emerged in the 1940 s as a key term and idea as part of the "welfare internationalism" of that decade, reflecting visions of a new post-war order (Kaufmann 2012: chapter 4). The term was mentioned in the Atlantic Charter of 1941, and the ILO used the term from 1940 onwards, officially from 1942 (Berten 2020). Latin American countries also took up the term at the Inter-American Conference on Social Security in Santiago de Chile in 1942. Although social security was defined rather narrowly at the conference, it was set in a wider context: the conference emphasised "the role of social insurance as the principal method of organising social security ... social security policy ... demands for its success concurrent measures to promote full employment, to increase national income, to raise the standard of living and education upon which health and capacity depend" (Inter-American Conference on Social Security 1942: 688).

From then on, the concept quickly spread globally, although (or just because) international organisations and states both interpreted it in very diverse ways. In 1948, social security became a human right under the newly founded United Nations' Universal Declaration of Human Rights. However, Article 22, which lays down the right, and Article 9 of the International Covenant on Economic, Social and Cultural Rights (ICESCR) of 1966, which restates this right in a more binding way, have just one sentence on this right, much less than for other rights. The articles name no standard and no agent in charge of specifying and implementing the right. This was left to the ILO (Davy 2014), which issued the key Convention no. 102, the "Social Security (Minimum Standards) Convention" (ILO 1952). The ILO tended to refer to the term narrowly as social insurance but had mentioned social assistance in many documents right from the beginning (Berten 2020). Out of our four countries, only Brazil has ratified Convention no. 102, but all have ratified the ICESCR, although South Africa did so as late as 2015 (see Table 1.1 in Chap. 1).

The use of the term "social security" in relevant political contexts indicates the emergence of a substantial understanding of the social in four respects.

First, social security is a comprehensive term that may cover a range of welfare policies and programmes. The use of the term indicates that the 
country in question has developed an overarching notion of the various common insecurities in individuals' lives and the need for political responses. To confront the "Five Giants"-Want, Ignorance, Disease, Squalor, and Idleness_-William Beveridge in his report of 1942 designed a "plan for social security": "it is a plan all-embracing in scope of persons and of needs" (Beveridge 1942: 9). At the time, "social security" was a very recent term, and, although it pervades Beveridge's report, the report was actually entitled "Social Insurance and Allied Services". The term "social insurance" had played an overarching role before in policies and programmes, but a truly overarching term had been missing in the interwar years (Berten 2019, 2020). "Social security" is potentially broader in scope than "social insurance", in particular because it includes noncontributory benefits for the poor, and, if fully realised, social services (Kaufmann 1973: 95).

Second, as Kaufmann emphasises, social security has a double character, denoting a set of welfare programmes and services as well as an idea, namely that the state should ameliorate the insecurity of its citizens' lives in a comprehensive sense. While the English language only has one term, "social security", the German distinction between soziale Sicherung, which denotes the institutional side, and soziale Sicherheit, which denotes the guiding idea, reflects the two sides of social security. When the idea of "social security" emerged globally in the 1940s, it was associated with visions of a new post-war society and new welfare ideas like prevention and rehabilitation (Kaufmann 1973: 95-98). However, it was a vision without specific instruments, "a normative concept ... in search of institutional realisations” (Kaufmann 1973: 98; transl. L.L.). This might help to explain its trajectory, and it demonstrates that powerful ideas may take precedence over actual social protection measures.

The advent of the concept of social security also historically signalled a transition from the labour question to more universalistic ideas of inclusion. In the Global North after World War II, social policy changed in character from class-based politics, which had emphasised collective labour rights, working conditions, and "labour insurance", to redistributive policies for all citizens in order to enhance individual welfare-_"social security" (Kaufmann 2013b). Redistribution was not so much between classes, but between older persons and the young (in the form of old-age 
pensions and long-term care, often based on the idea of a contract between generations), between the sick and the healthy (in the form of medical services), and between families and persons without children.

Third, unlike traditional poor relief and charity, but similar to social insurance, social security is not only about welfare provisions in the here and now but also oriented to the future, ${ }^{5}$ both providing and requiring a "long view" by citizens (de Swaan 1988, using a term by Norbert Elias). The designated outcome of social security programmes is not only financial betterment but also "security" for citizens in planning their lives. The idea of security includes self-assurance as psychological security of the self (Kaufmann 1973, ch. 4.5). Von Benda-Beckmann and von BendaBeckmann (1994) have challenged the view that traditional societies in the Global South lack a concept of social security because their members are absorbed by daily exigencies, unable to plan for the future. Based on research in Indonesia, the von Benda-Beckmanns argue that traditional societies also have a notion of the future and develop distinct ideas of and rules for social security. However, social security is mostly embedded in functionally diffuse social settings like the family, kinship, and the village.

Fourth, social security reflects a reformist strategy, with an emphasis on achieving security within capitalism rather than challenging the structural inequalities of capitalism (Heclo 1995: 667). The above quote from Marx reads in full: "Security is the supreme social concept of civil society, the concept of the police. The whole society exists only in order to guarantee for each of its members the preservation of his person, his rights, and his property" (Marx 1978: 43). ${ }^{6}$ That is, the concept of security is geared to securing rather than transcending civil society or capitalism (Marx 1956: 36). The idea of preserving a person and the person's rights and property, if extended to the social, encapsulates the thrust of the concept of social security or even the welfare state. Social security is about the livelihood of persons, their social rights, and "social property". Entitlements to social security, especially through social insurance

\footnotetext{
${ }^{5}$ On the temporality of the idea of security in general see Kaufmann (1973: ch. 4.3).

${ }^{6}$ German original: "Die Sicherheit ist der höchste soziale Begriff der bürgerlichen Gesellschaft, der Begriff der Polizei, daß die ganze Gesellschaft nur da ist, um jedem ihrer Mitglieder die Erhaltung seiner Person, seiner Rechte und seines Eigentums zu garantieren” (Marx 1956: 365f.; written in 1843).
} 
programmes, may acquire the legal status of property for the propertyless, as, for example, endorsed by the Supreme Court (Constitutional Court) in Germany (Zacher 2013: 95). Social security is about securing the livelihood of the wage labourer and other members of society, but leaves the basic relations of production intact, as does the general concept of security. The earlier concept of social insurance was similarly reformist, but social security implies a more far-reaching remoulding of living conditions under capitalism.

\section{Multireferentiality: Social Protection Is Largely Driven and Shaped by "Non-social" Ideas and Interests}

When talking about social policy ideas, one tends to think of "social" norms and values like social justice, solidarity, equality, and welfare. Such norms drive social movements and NGO work. Yet to promote social policies, referencing these norms is not enough. Kaufmann (1997, 2012: 277-285) holds that, historically, social policy in Europe only expanded because its collective utility beyond simply its welfare impacts-its economic, political, social, and cultural utility — could be demonstrated to the key actors. Similarly, Midgley (2013: 9-20) distinguishes several "functions of social protection" beyond the welfare function that need to be considered. Policymakers who seek to advance social policy need to create "synergies" between social and economic (and other) goals (Kaufmann 2012: 284; see also Rodgers 2013).

In all four countries references to the non-social functions of social protections figured explicitly and prominently in political debates. These references operated as frames of social protection, either supporting or countering extensions of social protection. This shows that opposition to social policy is not only about interests; rather, counter ideas are developed to justify the rejection of more substantial social protections. When tracing frames, we also found that counter ideas are more complex and less immediately interest driven than common terms like "neoliberalism" or, referring to South Africa, racism suggest. Marianne Ulriksen (Chap. 
7) concludes that "the apartheid state is a reminder of how far policy can be pushed with reference to ideational and normative justifications".

In the introduction, I distinguish between three types of frames: nonsocial frames, global frames, and counter frames (see the onion skin model, Fig. 1.2; for global frames see the next section). Social policy is not just underpinned by "social" ideas but relies on ideas originating from other spheres of society (Achinger 1979). These frames of the social differ between the four countries and across time: social security was conceived, alternatively, as facilitating, counteracting, or irrelevant to other, potentially broader societal concerns, especially economic growth, development, nation-building, social cohesion, and social peace. Surprisingly, the key arguments and contestations about social protections were similar in the four countries, and they also resemble debates in the Global North, with similar arguments and frames for or against social protection.

We identified a broad range of frames that operated in the four countries. In South Africa under apartheid and before, the "native question" was the racialised national question, and it framed the social question. The native question was about securing the white and Christian "civilisation" and, in conjunction, the racial hierarchy. In post-apartheid South Africa, developmentalism was used to protest the extension of social protections or at least was indifferent to them. Nelson Mandela and the African National Congress (ANC) were strong developmentalists. After apartheid, racial redress was another important frame that eclipsed the social question. However, anti-racism movements also helped to bring "dignity" to the fore, which became a key legitimising idea of more universalistic and rights-based social protection in the 2000s. Dignity is a strong frame because it is a basic value and can rally support from all political camps. In postcolonial India, the struggle for independence from foreign oppression and a developmentalist emphasis on economic growth tended to crowd out the social question. In China, securing social stability and the rule of the Communist Party have been the overarching frames of social protections in the reform era. In conjunction, the frame developmentalism or "GDPism" served to justify welfare retrenchment from 1978 to 2000. In Brazil and Argentina, developmentalist thinking was particularly influential in the 1950s and 1960s (Sikkink 1991). 
There were other influential frames. In South Africa, a moral frame gave rise to what I have described above as the deviance question. Ideas on creating an ecological society also came in at the end of our observation period, in the debate on land reform in Brazil. Religious frames also mattered. Neo-Calvinism acted as a counter frame to social protections in South Africa from the late 1930s onward, and the Hindu culture in India generally stifled the social question. Liberation theology in Brazil, inspired by left Catholicism, was a forceful movement in favour of farreaching social reforms.

Remarkably, reference to human rights sometimes counteracted the extension of social protections. According to T. H. Marshall (1950), citizenship is made up of three kinds of rights: political, civil, and social. Yet in political discourses, social rights often take a backseat, and social protections in particular are not "sexy". Calls for political and civil rights may crowd out demands for social rights. The fight against apartheid in South Africa was a case in point. It was primarily a fight for political and civil rights. Nelson Mandela was a freedom fighter and not much interested in issues of social protection. India has experienced strong movements for political and legal rights, while universal social rights are consistently underdeveloped. Political and legal equality can do little to counter the vast inequalities in Indian society. In international politics, for a long time, NGOs similarly focused on political and civil rather than social rights. For example, NGOs from all major political camps rejected or disregarded the idea of cash benefits for the poor well into the 1990s (Leisering 2019: 5f.).

Non-social ideas not only support or inhibit the extension of social protections but may also shape policies. Social ideas often mix with other ideas, leading to a hybridisation of the normative foundations of social protection, especially with regard to who is seen as deserving public benefits. For example, at the time of the early labour question, social protections were largely confined to industrial workers because they were seen as crucial to the economic development of the country. The social cash transfer programmes that have emerged since 2000 mostly focus on children (and older persons) while neglecting persons of working age. This reflects a developmentalist approach in a different way: the argument is that children are the economic agents of tomorrow (von Gliszczynski 
2015: 132f.). South Africa's post-apartheid social reformer Zola Skweyiya was a paternalist conservative who balanced the idea of a caring society with developmentalism, which resulted in a hybrid understanding of the state's social responsibilities.

Frames are not static; they may be interpreted in different ways and change over time. Economic arguments have been brought forward against and in favour of the extension of social protection. Social protection for industrial workers, for example, was meant to bolster the import substitution model of economic growth, as in Brazil. Christian ideas can equally work against or in favour of social protection, as neo-Calvinism in South Africa and the liberation theology in Brazil illustrate. Proponents of social protection may also be ambivalent about the extension of social protections, for example, the National Party under apartheid South Africa or the ANC after apartheid.

\section{Transnational Diffusion: External Ideas Have Pervaded Domestic Debates on Social Protection from the Beginning (the 1920s)}

All four countries have experienced external influence in one way or another. Colonisation was Northern powers' most direct inroad into the Global South but in the strict sense, only one of the four countries was a colony, India under the British Raj, while South Africa and Brazil were not simply colonised but also settled by farmers, workers, and slaves at different stages, and China experienced "externally-induced modernisation" (see Table 1.1 in Chap. 1). Some colonial rulers introduced rudimentary social protections and shaped administrative traditions that have repercussions till the present day. ${ }^{7}$ For settler societies, one can generally assume that the legacy of the settlers' countries of origin-Portugal, Britain, the Netherlands, Germany_-played a role, and that later associations, especially the Commonwealth, had an influence on the nation's historical trajectory.

\footnotetext{
${ }^{7}$ See Schmitt (2015) and Leisering (2019: 157) on present-day differences between anglophone and francophone countries in Africa.
} 
Is there a reason to assume a wholesale domination by Northern powers? Or do Northern perspectives on the Global South unduly obscure indigenous ideas and practices? It is generally plausible to assume that external ideas had a formative influence on the field of social protection for several reasons (see Chap. 1: availability of Northern models, lack of domestic expertise, and international organisations' and donors' activity).

The chapters in this volume provide ample evidence that external ideas-concepts pertaining to society and social welfare, institutional models of welfare, and expert knowledge-were omnipresent in all four countries - even in China under authoritarian rule after 1949, the Communist Party's claim to self-governance notwithstanding. Our findings align with a key tenet of the bourgeoning literature on diffusion and policy transfer, namely that external ideas are not usually simply transplanted to the receiving country but are subject to translation, adaptation, interpretation, syncretisation, and combination with domestic ideas. Communism became Sino-communism in China. "Socialism" in India did not mean the overthrow of capitalist society, but a kind of etatism as explained above. In the Indian state of Kerala, the Communist Party had a strong nationalist tendency (Singh 2015a). The concept of social insurance, which the ILO propagated, took on different shapes in the countries of the South (for Brazil see Lewis and Lloyd-Sherlock 2009), and the socialist countries, including China in the 1950s, adopted the etatiste Stalinist version of social insurance rather than the Bismarckian (Hu and Manning 2010). In the 2000s, China almost completely copied the German model of industrial accident insurance but did not adopt the self-governance in the administration of the insurance, which was seen as a threat to Party rule (Liu and Leisering 2017). Our findings also confirm the general insight of diffusion research that "decoupling" (Meyer 2009: 182) between the adoption of international norms and ideas, on the one hand, and domestic policies, on the other hand, is endemic.

Some Latin American countries, including Brazil, were remarkably independent early proponents of extensive welfare commitments by governments and even pushed Northern governments to do more in international arenas. Latin American governments - not the Soviet Union as is sometimes assumed-were key drivers of social rights in the years 
1946-1948 in the preparation of the Universal Declaration of Human Rights (Davy 2013, 2014).

From the late twentieth century onwards, there were two almost parallel but incongruous ideational movements. ${ }^{8}$ Economic liberalisation and marketisation, often described as "neo-liberalism", became globally hegemonic doctrines in the 1980s and 1990s that thoroughly transformed domestic politics worldwide, including our four countries (for the global spread of liberalization as a process of diffusion, see Simmons et al. 2008). This shift even affected "socialist" China, where it triggered economic reform and the attendant liberal break in social protection. However, almost simultaneously, from the 1990s onwards, an individualised understanding of social human rights also spread: the right to social security was interpreted as denoting individual entitlements to public benefits, superseding earlier collectivist, developmental or socialist, understandings (Davy 2013, 2014). The reference to "rights" and "rights-based" programmes and policies became part of the social discourse, and international organisations used this discourse to mobilise action on social protection and other social concerns. The new rights discourse also found its way into domestic politics, especially in South Africa and even in China during the 2000s and early 2010s. In operative terms, international organisations increasingly pushed for the extension of social protection through global campaigns and interventions in Southern policies (for social cash transfer programmes see von Gliszczynski 2015). From the early 2000s, even the ILO eventually took to actively advocating for non-contributory social cash transfers besides social insurance under the flag of "Social Security for All” (ILO 2003; see Leisering 2020). Brazil's, China's, and South Africa's pioneering models of social cash transfers (see Table 1.1 in Chap. 1) came earlier, though, testifying to a "development revolution from the global South" (Hanlon et al. 2010).

Our findings challenge two frames of reference of much of the policy transfer literature. First, the literature mostly analyses the activity of one sending agent, be it an international organisation or another country.

\footnotetext{
${ }^{8}$ In international politics, Koehler (2015: 740f.) identifies a related disjunction between the "first UN" and the "second UN". In the UN system, neoliberalism came to dominate the "first UN", that is, the member states, while the "second UN", that is, the UN secretariat and UN agencies, restored the UN's ideals of the UN Charter by calling for social justice and human rights.
} 
Second, studies mostly investigate the spread of policies - such as the World Bank's global campaign for a larger share of private old-age security in the 1990s and 2000s. In contrast, we detected a multiplicity of external agents and influences that shape several layers of the social (rather than only policies).

First, regarding the multiplicity of external agents, a range of Northern welfare states acted as agents of diffusion. British ideas, such as the Beveridge Report of 1942, impacted debates in India and South Africa. South African politicians observed not only models from Commonwealth countries, especially New Zealand and Australia, but also US casework models. The Netherlands played a role in South Africa's societal development through Dutch neo-Calvinist theologians. The German model of social insurance, which the ILO had taken up, was influential worldwide, except in socialist countries. However, in the reform era, even China adopted a Bismarckian industrial accident insurance programme. Marxism, originating in Germany, was a major influence on China since the 1920s. The Soviet Union influenced Chinese thinking as early as the 1920 s and 1930s and more forcefully so after the Communist revolution in 1949, by spreading the Soviet Union's model of industrial development and the Stalinist model of labour insurance. Ideas from the Soviet Union also resonated in India. Furthermore, there were countries that acted as mediators between Northern and Southern ideas, above all Japan, which had taken in Northern ideas as early as the nineteenth century and influenced Chinese thinking before 1949. South Korea also acted as mediator. The Soviet Union was a mediator of Marxist ideas.

International organisations were also active in disseminating ideas around the world. Meyer (2009) conceives of these organisations as key proponents of "world culture", that is, globally shared principles—such as universalism, individualism, rationalism, and human rights - and models - such as statehood, constitutions, and education. The ILO was founded in 1919, with India as a founding member. The creation of the United Nations in 1945 and the Universal Declaration of Human Rights of 1948 gave rise to a diversifying landscape of international organisations, both governmental and non-governmental, that would become major social policy actors from the 1990s onwards (Deacon et al. 1997), such as UNICEF, the World Health Organization (WHO), the Food and 
Agriculture Organization of the UN (FAO), the United Nations Development Programme (UNDP), plus national development agencies and donors. The ILO, the key player in the field of social protection since the interwar years, lost its hegemony. Global religious organisations also played a role. The Latin American liberation theology echoed the new thinking of the Second Vatican Council (1962-1965).

Diverse diffusion mechanisms were operative. Emulation, rather than policy learning, was frequent. Emulation is about receiving socially accepted ideas from select senders, that is, it is about social construction (e.g. of social problems and models of social security) rather than the close empirical observation and hard evidence that characterises policy learning (Dobbin et al. 2007: 450-454).

More concrete mechanisms of dissemination included the translation of Western academic literature, which was influential in domestic debates on "social problems", "social policy", and modernisation in China in the 1920s, and academic study abroad by thousands of Southern intellectuals. In China, students returning from Japan, Europe, and the USA discussed Marxist and non-Marxist concepts of society. The key architect of apartheid Hendrik Verwoerd and the major reformer in post-apartheid South Africa Zola Skweyiya both studied in Germany. During the last decade of apartheid, external pressure from the global public helped to loosen the hold on power of the racist regime.

These multiple external influences interacted in various ways. A synthesis of external influences, combined with domestic ideas and practices, may give rise to unique national solutions. The Chinese social assistance programme Dibao is a case in point (Leisering et al. 2017). The strength of various external influences also varied over time. China was the most extreme case among our four countries, switching to Soviet ideology in 1949 (before, the Communist Party had only been active in some regions) and repeatedly changing between external models in the field of old-age security during the reform era (Hu 2015, 2016). The conspicuous swings in social policy in China after 1978 pinpointed by Shih-Jiunn Shi partially happened in conjunction with swings in references to external models.

Second, regarding the multi-layered nature of external influences, we found that external influences operated on each of the four layers of the 
onion skin model, rather than only on the policy level, and that the influences on the four layers were incongruent in some instances. Some influences only affected the most general layers - the state's social responsibility and the social question-without necessarily impacting policies or institutions. In the process, the language of social welfare changed to include new terms like "social insurance" and "social security" and, more recently, "social inclusion" or "social sustainability", but related changes in actual policies came much later or not at all ("decoupling”). In China, since 2012, it has worked the other way around. While China has been jettisoning references to rights and civil society, distancing itself from key "Western" ideas, actual social protection programmes remain largely unchanged. Some new social categories have even entered constitutions, thereby entrenching the social responsibility of the state. The Brazilian Constitutions of 1934 and 1946 reflected socially minded European constitutions, the Chinese constitution of 1946 adopted the term "social security", and, in 2004, even China added human rights to its Constitution as well as the aim of establishing a social security system.

All in all, the countries we study in this volume reveal a plethora of external influences but talk and action were often decoupled. Countries were subject to heterogeneous influences from several senders and in several layers of the social. An in-depth study of these types of diffusion processes remains a desideratum. Moreover, various influential senders that have exerted influence besides the ILO are not analysed in this volume.

\section{The Social Question in Flux: Diversification and Traps}

The four countries, except India, have achieved a degree of social protection coverage over the last hundred years, which ranks them among the leaders in the Global South (see Table 1.1 in Chap. 1). For some time, Western observers had held the view that India would demonstrate the superiority of democracy vis-à-vis communist China. However, around 1980, China took the lead in economic growth and, from the 2000s, also in the field of social protection. Will the four countries further expand 
their social protection systems, even become welfare states? Or will they remain stuck at the current level of social protection-a "middle social protection trap", similar to the much discussed "middle income trap" with regard to economic development?? Or will they even fall back? What social questions will be raised?

While Northern welfare states reached "growth to limits" (Flora 1986) in the 1980s, covering almost all citizens by all major social services, countries in the Global South, even the most advanced ones, are far from this state: a restricted range of programmes, patchy coverage, low benefit levels, uneven quality of services, weak implementation, and clientelism and corruption are all widespread and social spending remains low (see Fig. 1.5 in Chap. 1). In the Global South, countries with comprehensive and universalistic social service programmes are rare. Few Southern countries are "proto-welfare state regimes"(including Brazil; see Table 1.1 and the discussion in Chap. 1). Only 16 out of 148 Southern countries have put in place social cash transfers that provide basic income security for all citizens, at least by law (in 2012/13; Leisering 2019: 194), and this includes Brazil and China, and South Africa is close (see Table 1.1). Only 29 per cent of the global population, North and South, are covered by social protection programmes in all key areas of protection (ILO 2017: 168), often with limited benefits. All in all, despite recent extensions, Southern social protections remain precarious and moderate at best.

The success model of social protection in the Global North and main pathway to universalism, social insurance, remains structurally limited in the Global South, due to the large share of informal workers. Breman and van der Linden (2014) even see informal work as a global threat that increasingly extends to the Global North. Therborn (2019: ix) and Breman et al. (2019) see evidence of a new global social question revolving around multiple forms of precarious labour. Yet, the ILO (2015) sticks to the notion of formal employment and seeks to spread it worldwide, and thereby also social insurance (see historically Seekings 2008). The Indian government is increasingly providing social security like

\footnotetext{
${ }^{9}$ Real GDP per capita declined in Brazil during the 2010s and stagnated in South Africa (see Fig. 1.3 in Chap. 1).
} 
maternity allowances and small pensions to informal workers but disjointed from job security.

\section{"Exclusion/Inclusion": The New Social Question?}

The social question had already started to shift beyond the workers' question in the 1940s, with "social security" as an ideational horizon. South Africa had focused on non-workers as early as the 1920s, under the flag of the "poor white problem". Since the 1990s, the social question has further moved towards ideas of universalistic "inclusion". "Inclusion", "inclusiveness", and "inclusive policies" have become standard terms in the global development community's lexicon (e.g. UN 2018). Yet, the potential new social question "exclusion/inclusion" is less distinct than the labour question or the land question. "Inclusion" seems to provide an open platform that can accommodate a variety of ideas and concepts.

What aspects of the social does "inclusion" address? The concept goes beyond the problems of the capitalist labour market and inequalities of class, which defined the labour question. The contributors to this volume demonstrate that social issues revolve around a range of fundamental inequalities besides economic class, including ethnicity/"race", caste, gender, land ownership, and the urban/rural divide. "Inclusion" is a very broad term that would cover all these forms of inequality. However, the concept of inclusion extends even further, by highlighting a new facet of inequalities. "Inequality" is an abstract and impersonal term, whereas the language of exclusion/inclusion is often used to specify who exactly is excluded, who excludes, and from what it is that persons are excluded. This perspective has particularly been applied to issues of gender, to persons with disabilities, and "vulnerable" persons. The latter term denotes diverse groups, such as children, especially handicapped or orphaned children, persons with disability, older persons, or women.

There is another usage of "inclusion", which further differs from "inequality". While addressing social inequalities presupposes a comparison of a person's or group's position with that of another, pointing out deficient inclusion can also refer to socially defined standards, without necessarily or primarily involving comparisons. In this sense, inclusion is 
about enhancement, reflecting the welfare state's intellectual origins in the Enlightenment, especially the idea of the self-perfectibility of man (Janowitz 1976). Education and medical services, for example, aim to develop citizens' cognitive and physical capabilities. Amartya Sen (1983) links inequality and inclusion to emphasise the absolute core of relative poverty, arguing that economic inequalities (or relative poverty) may impair inclusion (defined in "absolute" terms of capabilities). Sen's concept of capabilities is part of this inclusion tradition, as is T. H. Marshall's concept of social citizenship (see Leisering 2019: 51f.).

In collective terms, enhancement may mean raising the general standard of living in poor countries, that is, tackling collective poverty rather than individual poverty or inequality in the first place. This concept of enhancement is akin to a developmental notion of welfare, which Drèze and Sen (1991: 22) call "growth-mediated security", which is marketdriven, in contrast to "support-led security" provided by the state.

Deficiency of inclusion is socially defined. From a constructivist perspective, social policy attends to forms of inclusion that political actors deem insufficient in view of socially defined standards (Kaufmann 2012: 153). Marshall (1950: 11) defines the substance of social citizenship in an open way by referencing "the standards prevailing in the society". The constructivist understanding opens up the concept of inclusion to a wide range of social issues: to diverse kinds of inequality and related exclusions, and to collective enhancement in respect to diverse aspects of living. In political terms, the openness of the concept of inclusion may thus enable consensus between different stakeholders. However, the openness of the forms and standards of inclusion also blurs the social question. Diverse interpretations are possible, giving rise to strong or weak, individualist or collectivist notions of the social question. ${ }^{10}$

Some authors see dependence/autonomy as the most fundamental social question and the core concern of the welfare state (Vobruba 1997; Leisering 2019: 49). Vocalising the social question as exclusion/inclusion is indifferent to the question of dependence/autonomy. Dependence/ autonomy reflects an individualistic interpretation of inclusion, which

\footnotetext{
${ }^{10}$ This is similar to the use of "universalism" by international organisations. "Universalism" belongs to the semantic field of "inclusion" and is also vaguely defined (see Leisering 2020).
} 
would, for example, require "de-familialisation" (Esping-Andersen 1999: 45) to secure individual autonomy particularly for women and children, analogous to and supplementing "decommodification" (Esping-Andersen 1990) in the labour market. By contrast, conservatives and socialists tend to conceive of including persons as members of their families or other collectivities, with pre-defined rights and duties, rather than individual rights bearers. ${ }^{11}$ Autonomy would also require de-clientelisation of social relationships. Clientelism and patronage is especially widespread in the Global South and a major concern for social policymakers (Wood and Gough 2006: 1707-1709).

What is the future of the social question if defined as social exclusion/ inclusion? I have distinguished three facets of social questions: "objective" socio-economic conditions, the articulation of problematic conditions as societal concerns, and welfare institutions set up in response. The first and third facets indicate problems that could limit or even halt the further extension of social protections in many countries in the Global South. I postulate that there are two potential traps: the "residualism trap", which refers to welfare institutions (third facet), and the "inequality trap", which refers to socio-economic conditions (first facet).

\section{The Residualism Trap}

Several countries in the Global South, including our four countries, have a reasonable amount of economic resources and administrative expertise to plan and create substantial welfare institutions. Indicators like education, literacy, means of transport, or the use of digital technologies have all improved, even in many poorer countries. However, with rising social problems and expectations, more resources will be needed. For example, health services for all citizens according to the standards of Western and Northern European welfare states, or comprehensive social assistance to those in need, are currently elusive for Southern countries. In consequence, as long as countries are caught in a middle-income trap, it is unlikely they will escape a middle-social protection trap.

\footnotetext{
${ }^{11}$ I owe this distinction to Jeremy Seekings.
} 
Rising expectations are particularly pronounced among members of the middle class who aspire to Northern standards of public welfare, such as generous pensions and high-quality health services. However, "inclusion" is often meant to be achieved through universal welfare programmes, which tend to provide meagre flat-rate benefits to all citizens, such as non-means-tested, non-contributory pensions and low-quality services. Such programmes may be appropriate in societies in which most people are in or near poverty but tend to be less attractive for the rising middle class, who then invest in private provisions. If many members of the middle class have done so, it might be too late to win them back to statebased provisions. As a result, the middle classes' political support for public welfare will dwindle, the fiscal space also for services for the poor will shrink, and the universalistic services for the poor will become residual $^{12}$ - a residualism trap. In addition, demographic ageing might be too advanced in some countries, especially in China, to make the case for large-scale contributory and earnings-related old-age pensions.

\section{The Inequality Trap}

Economic inequality is extreme in all four countries and has risen massively in the wake of neoliberal policies since the 1990s (see Fig. 1.4 in Chap. 1). ${ }^{13}$ Social cash transfers to the poor have tangibly reduced extreme poverty in many countries but have hardly affected inequality (World Bank 2018: 61; for Brazil and South Africa see Barrientos et al. 2013). Social protection in general has done little to reduce inequality ${ }^{14}$ and has even produced massive new cleavages (for socialist China see Dillon 2015). Social inequalities in the four countries have seemingly become too exaggerated to be contained by social protection programmes. Social

\footnotetext{
${ }^{12}$ See Esping-Andersen (1990: 25), Korpi and Palme (1998), and the discussion in Leisering (2019: 340-343).

${ }^{13}$ For inequality and stratification in the four countries, see generally Li et al. (2013) and Frazier (2011).

${ }^{14}$ For welfare outcomes of social policies in the BRICS countries, see Maiorano and Manor (2017), for the role of employment policies for income inequality see OECD (2010). In a major study of the relationship between social protection and inequality, Midgley (2020) revitalises the egalitarian claim of social protection.
} 
protection policies are facing the challenge of switching from "easy redistribution" to "hard redistribution" (Holland and Schneider 2017).

Wulfgramm and Starke (2017) argue that in societies with extreme socio-economic inequalities, attempts at more far-reaching redistribution can become divisive. Based on data that includes Brazil, South Africa, and other middle-income countries, they find (2017: 20f.) that "both market inequality and state redistribution have dividing effects on public opinion... while the problem of income inequality certainly is driving a wedge into societies, the solution of more redistribution may be equally divisive from a certain level onwards... for progressive policy advocates in advanced welfare states, keeping the primary distribution of incomes in check may be preferable to further redistribution in order to avoid a more divided public... However, ... many of the institutional preconditions of egalitarian 'predistribution'... may be extremely difficult to create and sustain in countries without historical precedent". That is, even if social protection policies escaped the residualism trap and achieved hard redistribution, they risk being divisive, not to mention that changes in primary distribution are beyond the reach of social protection policies.

At this point, we are reminded of the reformist nature of the social question concept. Marx scorned the reformist ideas of his time. In his 1875 Kritik des Gothaer Programms (Critique of the Gotha Programme) —a critique of the draft of a programme for a unified social-democratic workers' party in Germany-Marx criticised the expression "social question" as empty journalist talk that suggested a state-led strategy, as opposed to class struggle that would bring down capitalism. That is, Marx rightly saw the "social question" as the key semantics of the then-emerging reformist concept of "social policy":

the physic of the prophet! ... In place of the existing class struggle appears a newspaper scribbler's phrase: 'the social question', to the 'solution' of which one 'paves the way'. Instead of arising from the revolutionary process of transformation of society, the 'socialist organization of the total labour' 'arises' from the 'state aid' that the state gives to the producers' co-operative societies and which the state, not the workers, 'calls into being'. It is worthy 
of Lassalle's imagination that with state loans one can build a new society just as well as a new railway! (Marx 1977: n.p. $)^{15}$

In fact, social protection policies in the South have left private ownership of the means of production and capital largely untouched. Capitalism — more precisely: predatory capitalism and oligarchical rulehas persisted, most visibly in Brazil and South Africa, or has appeared in a new guise in China, combining state capitalism with oligarchical Party rule. The earliest form of the social question, the land question, was about property, but no thoroughgoing land reform has ever been achieved, except for China in the early years after the communist revolution, although the reform was dismantled during the era of socialist transition (1953-1956) with the agricultural collectivisation, which in turn has been tacitly upturned during the era of expanding state capitalism. In Brazil, even Duguit's reformist concept of a "social function of property", despite its prominent place in the constitution, had little substantive impact.

Marx, in the above quote, asserted the limitations of "state aid" for workers in the face of the structural constraints of capitalism and pleaded for class struggle instead. Pellissery et al. (2015) extend Marx' argument beyond capitalist structures and economic inequalities. They demonstrate that both targeted and universalistic social protection policies cannot redress the "durable inequalities" of caste in India, but that political participation and mobilisation are needed to bring about structural change.

All in all, social protection policies in the four countries might be trapped by extreme inequalities and the residualist tendencies of inclusive welfare institutions. While reformist social strategies are subject to these traps, socialist social protections put in place in China between 1949 and 1978 are no solution either, since they provided minimal security at best

\footnotetext{
${ }^{15}$ German original: “das Heilmittel des Propheten! ... An die Stelle des existierenden Klassenkampfs tritt eine Zeitungsschreiberphrase- die soziale Frage, deren Lösung man 'anbahnt'. Statt aus dem revolutionären Umwandlungsprozesse der Gesellschaft 'entsteht' die 'sozialistische Organisation der Gesamtarbeit' aus der 'Staatshilfe', die der Staat Produktivgenossenschaften gibt, die er, nicht der Arbeiter, ins Leben ruft. Es ist dies würdig der Einbildung Lassalles, daß man mit Staatsanlehn ebensogut eine neue Gesellschaft bauen kann wie eine neue Eisenbahn!” (Marx 1962: 26).
} 
in a society characterised by collective poverty. ${ }^{16}$ Moreover, social protection in socialist China was highly stratified (Dillon 2015). Developmentalist strategies geared to growth-mediated security (be it through markets or a socialist command economy) are no cure either; they have produced the high levels of inequality in the first place and are prone to incur environmental damages with new problems of securing livelihoods. Both socialist and unfettered developmentalist strategies fail to give adequate attention to the exigencies of social protection.

Since the 2010s, all four countries studied in this volume have had radical leaders-Bolsonaro, Modi, Xi Jinping, and Zuma (the latter till 2018) — who took to nationalist policies, which are, sociologically speaking, a functional equivalent to social policy as means of societal integration, especially in times of abating economic growth rates.

\section{Renewing the Social Question}

Authors in the Marxist political economy tradition, such as Breman et al. (2019) and Therborn (2019), paint a gloomy picture of the future of the global social question, focused on the global spread of precarious labour. ${ }^{17}$ Nor do the residualism and inequality traps promise a glamorous future.

Yet, when examining the core facet of the social question - the articulation of problematic conditions as societal concerns-a somewhat brighter picture emerges. From the angle of neo-institutionalist world society theory, Meyer (2009: 199) argues: "the growing list of perceived 'social problems' in the world indicates not the weakness of world-cultural institutions but their strength. .... A world with so many widely discussed social problems is a world of Durkheimian and Simmelian integration, however much it may also seem driven by disintegrative tendencies". However, do these global perceptions and discussions actually matter? International organisations operate with a surplus of "social" ideas, as Southern countries have also increasingly done since the 1990s.

\footnotetext{
${ }^{16}$ For the predicaments of socialist social policies in a relatively well-off country, the German Democratic Republic (1949-1990), see Schmidt (2013).

${ }^{17}$ Interestingly, Therborn (2019: ix) also speaks of "inclusion" as the new social question but conceives of it in narrow labour terms.
} 
Representations and recognition of social problems and problem groups abound, but they are only loosely coupled with actual measures and are often phrased in vague terms (see Leisering 2020 for the indistinctive use of "universalism" in global debates). However, several studies by Meyer and associates and other authors show that international organisations' ideas and models do influence domestic policies, even if only in the long run (for social pensions see Böger and Leisering 2020).

Furthermore, global discussions have been broadening, effecting a diversification of the social question. Over the last two decades, migration, climate change, environmental decay, global epidemics, and digitalisation have emerged as new (or newly addressed) global phenomena that raise issues of exclusion and inclusion. In the process, new ideational resources and frames from these "non-social" spheres may revitalise the social question. For example, the concept of "sustainability" ties the social question to the ecological question, which has a broader constituency and more political clout. Hybrid terms like "social sustainability" and "social and ecological sustainability", as addressed in the UN Sustainable Development Goals of 2015, redefine the concept of development as well as the role of social protection policies. Climate activists, the digital community, gender-rights advocacy groups, and the disability movement also bring new power and ideas to social policies. However, the challenges of hard social divisions by race (South Africa, Brazil), caste (India), class, and gender (all four countries) remain.

The future seems neither gloomy nor bright, but diverse. Some countries are pursuing more successful reformist strategies than others. It might be that a few Southern countries will build up a generous, wellmanaged, and rights-based architecture of social protections that includes all strata of society, based on a culture of publicly addressing the social question and a socially responsible state. The common reference to "Northern welfare states" obscures that even in the Global North, genuine welfare statism in this cultural sense is largely confined to a few countries in Western and Northern Europe and the Commonwealth (Kaufmann 2013a, c). 


\section{References}

Achinger, Hans (1979) Sozialpolitik als Gesellschaftspolitik. Von der Arbeiterfrage zum Wohlfahrtsstaat, 3rd ed. Frankfurt am Main: Eigenverlag des Deutschen Vereins für öffentliche und private Fürsorge (first published 1958).

Ahuja, Ravi (2018) The similar yields divergence. Global notions of "social welfare" and the making of "informality" in twentieth-century India. In Similarity. A paradigm for culture theory, eds. Anil Bhatti and Dorothee Kimmich. New Delhi: Tulika Books, 311-333.

Barrientos, Armando, Valerie Møller, João Saboia, Peter Lloyd-Sherlock, and Julia Mase (2013) 'Growing' social protection in developing countries: lessons from Brazil and South Africa. Development Southern Africa 30, 1: 54-68.

Berten, John (2019) Failed indicatorisation: Defining, comparing and quantifying social policy in the ILO's international survey of social services of the interwar period. Historical Social Research 44, 2: 175-201.

Berten, John (2020) Laboratories of social knowledge: how international organizations constructed social policy through numbers, 1919-2015. PhD thesis, Bremen: Bremen University.

Beveridge, William (1942) Social insurance and allied services. Report. London: HMS.

Böger, Tobias and Lutz Leisering (2020) A new pathway to universalism? Explaining the spread of "social" pensions in the Global South, 1967-2011. Journal of International Relations and Development 23: 308-338.

Breman, Jan and Marcel van der Linden (2014) Informalizing the economy: the return of the social question at a global level. Development and Change 45, 5: 920-940.

Breman, Jan, Kevan Harris, Ching Kwan Lee, and Marcel van der Linden (2019) Postscript: the social question in its global incarnation. In The social question in the twenty-first century: a global view, eds. Jan Breman, Kevan Harris, Ching Kwan Lee, and Marcel van der Linden, University of California Press, 244-250.

Castel, Robert (2003) From manual workers to wage laborers. Transformation of the social question. Transaction Publishers (republished by Routledge 2017; French 1995).

Davy, Ulrike (2013) The rise of the "global social": origins and transformations of social rights under UN Human Rights Law. International Journal of Social Quality 3, 2: 41-59. 
Davy, Ulrike (2014) How human rights shape social citizenship: on citizenship and the understanding of economic and social rights. Washington University Global Studies Law Review 13: 201-263.

de Swaan, Abram (1988) In care of the state. Health care, education and welfare in Europe and the USA in the modern era. Oxford, New York: Oxford University Press.

Deacon, Bob, with Michelle Hulse and Paul Stubbs (1997) Global social policy. International organizations and the future of welfare. London et al.: SAGE.

Dillon, Nara (2015) Radical inequalities. Chinas revolutionary welfare state in comparative perspective. Cambridge, Mass., and London: Harvard University Press.

Dobbin, Frank, Beth Simmons, and Geoffrey Garrett (2007) The global diffusion of public policies: social construction, coercion, competition, or learning? Annual Review of Sociology 33: 449-472.

Drèze, Jean and Amartya K. Sen (1991) Public action for social security: foundations and strategy. In Social security in developing countries, eds. Ehtisham Ahmad, Jean Drèze, John Hills, and Amartya K. Sen, Oxford: Clarendon Press, 3-40.

Esping-Andersen, Gøsta (1990) The three worlds of welfare capitalism. Cambridge: Polity Press.

Esping-Andersen, Gøsta (1999) Social foundations of postindustrial economies. Oxford: Oxford University Press.

Flora, Peter (ed.) (1986) Growth to limits: the Western European welfare states since World War II. Two vols. Berlin: de Gruyter

Frazier, Mark W. (2011) Welfare policy pathways among large uneven developers. In Beyond the Middle Kingdom. Comparative perspectives on China's capitalist transformation, ed. Scott Kennedy. Stanford: Stanford University Press, 89-109.

Hanlon, Joseph, Armando Barrientos, and David Hulme (2010) Just give money to the poor: the development revolution from the global South. Sterling: Kumarian Press.

Heclo, Hugh (1995) The social question. In Poverty, inequality, and the future of social policy. Western states in the new world order, eds. Katherine MacFate, Roger Lawson, and William Julius Wilson, New York: Russell Sage Foundation, 665-692.

$\mathrm{Hu}$, Aiqun and Patrick Manning (2010) The global social insurance movement since the 1880s. Journal of Global History 5, 1: 125-148. 
$\mathrm{Hu}$, Aiqun (2015) China's social insurance in the twentieth century: a global historical perspective. Leiden: The Brill Academic Publisher.

$\mathrm{Hu}$, Aiqun (2016) Social insurance ideas in the People's Republic of China: a transnational and historical analysis. Transnational Social Review 6, 3: 297-312.

Holland, Alisha C. and Ben Ross Schneider (2017) Easy and hard redistribution: the political economy of welfare states in Latin America. Perspectives on Politics 15: 988-1006.

ILO (1925) General problems of social insurance. International Labour Office, Studies and Reports, Series M. (Social Insurance) - No 1. Geneva: ILO

ILO (1952) Social Security (Minimum Standards) Convention, C102, 28 June 1952, Geneva: ILO.

ILO (2003) Global Campaign on Social Security and Coverage for All. http:// www.ilo.org/public/english/protection/socsec/pol/campagne/index.htm (accessed 10 May 2020).

ILO (2015) Transition from the informal to the formal economy. Recommendation R204, 12 June 2015, Geneva: ILO.

ILO (2017) World Social Protection Report 2017-19. Universal social protection to achieve the Sustainable Development Goals. Geneva: ILO.

Inter-American Committee on Social Security (1942) A new structure of social security: the work of the Inter-American conference on social security at Santiago de Chile. International Labour Review 46, 6, 661-691.

Janowitz, Morris (1976) Social control of the welfare state. New York: Elsevier.

Kaufmann, Franz-Xaver (1973) Sicherheit als soziologisches und sozialpolitisches Problem. Untersuchungen zu einer Wertidee hochdifferenzierter Gesellschaften. 2nd rev. ed., Stuttgart: Enke.

Kaufmann, Franz-Xaver (1997) Herausforderungen des Sozialstaates. Frankfurt am Main: Suhrkamp.

Kaufmann, Franz-Xaver (2012) European foundations of the welfare state. New York et al.: Berghahn Publishers.

Kaufmann, Franz-Xaver (2013a) Variations of the welfare state. Great Britain, Sweden, France and Germany between capitalism and socialism. German Social Policy 5, ed. Lutz Leisering. Berlin: Springer (first published in German 2001/2003).

Kaufmann, Franz-Xaver (2013b) Thinking about social policy. The German tradition. German Social Policy 1, ed. Lutz Leisering. Berlin et al.: Springer (first published in German 2001/2003).

Kaufmann, Franz-Xaver (2013c) The idea of social policy in Western societies: origins and diversity. International Journal of Social Quality 3, 2: 16-40. 
Koehler, Gabriele (2015) Seven decades of "development", and now what? Journal of International Development 27, 6: 733-751.

Korpi, Walter and Joakim Palme (1998) The paradox of redistribution and strategies of equality: welfare state institutions, inequality and poverty in the Western Countries. American Sociological Review 63, 5: 661-687.

Leisering, Lutz (2019) The global rise of social cash transfers. How states and international organizations constructed a new instrument for combating poverty. Oxford et al.: Oxford University Press.

Leisering, Lutz (2020) The calls for universal social protection by international organizations: constructing a new global consensus. Social Inclusion 8, 1: $90-102$.

Leisering, Lutz, Tao Liu, and Tobias ten Brink (2017) Synthesizing disparate ideas: how a Chinese model of social assistance was forged. Global Social Policy 17, 3: 307-327.

Leisering, Lutz, Gong Sen and Athar Hussain (2002) Old-Age Pensions for Rural China? From Land Reform to Globalization. Report for the Development Planning Commission of the Peoples Republic of China and the Asian Development Bank (ADB), Beijing/Manila/Bielefeld.

Lewis, Colin M. and Peter Lloyd-Sherlock (2009) Social policy and economic development in South America: an historical approach to social insurance. Economy and Society 38, 1: 109-131.

Li, Peilin, M.K. Gorshkov, Celi Scalon, and K.L. Sharma (eds.) (2013) Handbook on Social Stratification in the BRIC Countries. New Jersey et al.: World Scientific.

Liu, Tao and Lutz Leisering (2017) Protecting injured workers: how global ideas of industrial accident insurance travelled to China. Journal of Chinese Governance 2, 1: 106-123.

Maiorano, Diego and James Manor (2017) Poverty reduction, inequalities and human development in the BRICS: policies and outcomes. Commonwealth \& Comparative Politics 55, 3: 278-302.

Marshall, Thomas H. (1950) Citizenship and social class. In Thomas H. Marshall, Citizenship and social class and other essays, Cambridge: Cambridge University Press, 1-85.

Marx, Karl (1956) Zur Judenfrage. In Karl Marx Friedrich Engels, Werke, vol. 1, Berlin: Dietz, 347-377 (written 1843).

Marx, Karl (1962) Kritik des Gothaer Programms, In Karl Marx Friedrich Engels, Werke, vol. 19. Berlin: Dietz, 15-32 (written 1875).

Marx, Karl (1978) On the Jewish Question. In The Marx-Engels Reader. Edited by Robert Tucker, New York: Norton \& Company, 26-46. 
Marx, Karl (1977) Critique of the Gotha Programme. In Karl Marx Friedrich Engels, Selected works, Vol. 3, Progress Publishers, 13-30.

Meyer, John W. (2007) Globalization: Theory and Trends. International Journal of Comparative Sociology 48, 4: 261-273.

Meyer, John W. (2009) World society, eds. Georg Krücken, and Gili S. Drori, Oxford: Oxford University Press.

Midgley, James (1984) Social security, inequality, and the Third World. New York: John Wiley \& Sons.

Midgley, James (2013) Social protection in countries experiencing rapid economic growth: goals and functions. In Social protection, economic growth and social change. Goals, issues and trajectories in China, India, Brazil and South Africa, eds. Midgley, James and David Piachaud, Cheltenham/Northampton: Edward Elgar, 7-25.

Midgley, James (2020) Inequality, social protection and social justice. Cheltenham/ Northampton: Edward Elgar.

OECD (2010) Tackling inequalities in Brazil, China, India and South Africa. The role of labour market and social policies. OECD Publishing.

Pankoke, Eckart (1970) Sociale Bewegung, sociale Frage, sociale Politik: Grundfragen der deutschen "Socialwissenschaft" im 19. Jahrhundert. Stuttgart: Klett.

Pellissery, Sony, Amrutha Jose Pampackal, and Partha Bopaiah (2015) Caste and distributive justice: can social policy address durable inequalities? Social Policy \& Administration 49, 6: 785-800.

Pellissery, Sony and Ivar Lødemel (2020) Property and social citizenship: social policy beyond the North. Social Policy and Society 19, 2: 275-292.

Pereira, Carlos and Frederico Bertholini (2017) Beliefs or ideology: the imperative of social inclusion in Brazilian politics. Commonwealth \& Comparative Politics 55, 3: 377-401.

Petersen, Klaus and Daniel Béland (eds.) (2014a) Analysing social policy concepts and language. Comparative and transnational perspectives. Bristol: Policy Press. Petersen, Klaus and Daniel Béland (2014b) Conclusion: comparative perspectives on social policy language. In: Analysing social policy concepts and language. Comparative and transnational perspectives, ed. by Klaus Petersen and Daniel Béland. Bristol: Policy Press, 297-311.

Piachaud, David and James Midgley (2013) Conclusion: experiences, issues and future possibilities. In: Social protection, economic growth and social change. Goals, issues and trajectories in China, India, Brazil and South Africa, eds. Midgley, James and David Piachaud, Cheltenham/Northampton: Edward Elgar, 265-277. 
Rimlinger, Gaston V. (1971) Welfare policy and industrialization in Europe, America and Russia. New York: Wiley.

Rodgers, Gerry (ed.) (2013) Aligning economic and social goals in emerging economies. Employment and social protection in Brazil, China, India and South Africa. New Delhi: Academic Foundation.

Schmidt, Manfred G. (2013) Social policy in the German Democratic Republic. In Manfred G. Schmidt and Gerhard A. Ritter, The rise and fall of a socialist welfare state: the German Democratic Republic (1949-1990) and German Unification (1989-1994). German Social Policy, vol. 4, ed. Lutz Leisering, Berlin and Heidelberg: Springer, 23-166.

Schmitt, Carina (2015) Social security development and the colonial legacy. World Development 70: 332-342.

Seekings, Jeremy (2008) The ILO and Social Protection in the Global South, 1919-2005. ILO Century Project, Geneva: ILO.

Simmons, Beth A., Frank Dobbin, and Geoffrey Garrett (2008) Introduction: the diffusion of liberalization. In The global diffusion of markets and democracy, eds. Beth A. Simmons, Frank Dobbin, and Geoffrey Garrett, Cambridge: Cambridge University Press, 1-63.

Sen, Amartya K. (1983) Poor, relatively speaking. Oxford Economic Papers 35, 2: 153-169.

Sikkink, Kathryn (1991) Ideas and institutions: developmentalism in Brazil and Argentina. Ithaca, NY: Cornell University Press.

Singh, Prerna (2015a) How solidarity works for welfare. Subnationalism and social development in India. Cambridge: Cambridge University Press.

Singh, Prerna (2015b) Subnationalism and social development: a comparative analysis of Indian States. World Politics 67, 3: 506-562.

Therborn, Göran (2019) Preface: the terrifying convergence of the three worlds of the "social question". In: The social question in the twenty-first century: a global view, eds. Breman, Jan, Kevan Harris, Ching Kwan Lee, and Marcel van der Linden, University of California Press, ix-xii.

UN (2018) Promoting inclusion through social protection. Report on the World Social Situation 2018, New York: UN.

Usui, Chikako (1994) Welfare state development in a world system context: event history analysis of first social insurance legislation among 60 Countries, 1880-1960. In The comparative political economy of the welfare state, eds. Thomas Janoski and Alexander M. Hicks, Cambridge: Cambridge University Press, 254-277.

Vobruba, Georg (1997) Autonomiegewinne. Sozialstaatsdynamik, Moralfreiheit, Transnationalisierung. Vienna: Passagen. 
von Benda-Beckmann, Franz and Keebet von Benda-Beckmann (1994) Coping with insecurity. In Coping with insecurity. An "underall" perspective on social security in the Third World, eds. Franz von Benda-Beckmann, Keebet von Benda-Beckmann, and Hans Marks, Special Issue Focaal 22/23, Nijmegen: Focaal, 7-31.

von Gliszczynski, Moritz (2015) Cash transfers and basic social protection. Towards a development revolution? Basingstoke: Palgrave Macmillan.

World Bank (2018) The state of social safety nets 2018. Washington, DC: World Bank.

Wood, Geof and Ian Gough (2006) A comparative welfare regime approach to global social policy. World Development 34, 10: 1696-1712.

Wulfgramm, Melike and Peter Starke (2017) Divided by the market, divided by the state: distribution, redistribution and welfare attitudes in 47 countries. Scandinavian Political Studies 40, 1: 1-27.

Zacher, Hans F. (2013) Social policy in the Federal Republic of Germany. The constitution of the social. German Social Policy 3, ed. Lutz Leisering. Berlin and Heidelberg: Springer.

Open Access This chapter is licensed under the terms of the Creative Commons Attribution 4.0 International License (http://creativecommons.org/ licenses/by/4.0/), which permits use, sharing, adaptation, distribution and reproduction in any medium or format, as long as you give appropriate credit to the original author(s) and the source, provide a link to the Creative Commons licence and indicate if changes were made.

The images or other third party material in this chapter are included in the chapter's Creative Commons licence, unless indicated otherwise in a credit line to the material. If material is not included in the chapter's Creative Commons licence and your intended use is not permitted by statutory regulation or exceeds the permitted use, you will need to obtain permission directly from the copyright holder.

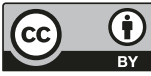

